\title{
Board Governance and Bank's Performance: Does Size Matter?
}

\author{
Atia ALAM', Syeda Fizza ABBAS ${ }^{2}$, Ameena HAFEEZ ${ }^{3}$ \\ Received: August 01, 2020 Revised: September 30, 2020 Accepted: October 15, 2020
}

\begin{abstract}
Over the last few decades, corporate frauds have highlighted the significance of corporate governance in deriving firm performance. By using different sample data, extensive research has examined how corporate governance structure influences firm's profitability, but limited research was undertaken on the banking sector of Pakistan. This research adds to the literature by testing how board structure derives bank's performance by using sample data of 19 banks for the period from 2010 to 2017 . In addition, the study analyzes the controlling part of size on the link between board governance and bank performance. Findings reveal that banks having small board size, fewer non-executive directors and minimum activity level perform better. Analysis related to bank size illustrates that board size has value in increasing benefits in large size banks in contrast to small size one, while higher participation by board members enhances performance of small size banks more. The correlation results and findings showed that there existed no multicollinearity issue between independent variables. Board size showed positive correlation with the market variable, while board activity tended to correlated negatively with the market performance. Inverse correlation between board size and independent directors indicated that Pakistani banks with greater board size had fewer independent directors.
\end{abstract}

Keywords: Board Structure, Performance, Moderation, Banking Sector, Pakistan

JEL Classification Code: C10, C12 G38, G21

\section{Introduction}

Separation between managers and owners has become a most debatable issue among researchers that led to the development of new and strict rules and regulations for corporations from the last few decades. The initiation of such rules and codes for corporate governance is no doubt a major achievement for practitioners, but still less compliance of such governance rules in underdeveloped countries hinders the firm's performance. Strong compliance of corporate governance, therefore, enables corporations to increase

${ }^{1}$ First Author and Corresponding Author. Assistant Professor, Business Studies Department, Kinnaird College for Women, Lahore, Pakistan [Postal Address: 93 Jail Road, G.O.R. -1, Lahore, Punjab, 54000, Pakistan] Email: atia.alam@kinnaird.edu.pk

${ }^{2}$ Assistant Professor, Accounting and Finance Department, Kinnaird College for Women, Lahore, Pakistan.

Email: fizza.abbas@kinnaird.edu.pk

${ }^{3}$ Accounting and Finance Department, Kinnaird College for Women, Lahore, Pakistan. Email: ameena.hafeez37@gmail.com

(c) Copyright: The Author(s)

This is an Open Access article distributed under the terms of the Creative Commons Attribution Non-Commercial License (https://creativecommons.org/licenses/by-nc/4.0/) which permits unrestricted non-commercial use, distribution, and reproduction in any medium, provided the original work is properly cited. earnings and to earn abnormal profits by acquiring low cost capital. Corporate frauds, all over the world, have proven that how weak board structure led firms to financial distress and bankruptcy. Governing bodies have identified Board of Structure as an important component of corporate governance (Jantadej \& Wattanatorn, 2020) and involved in continuous restructuring of roles and responsibilities of board in alignment with the dynamic market conditions. Without having corporate governance control, manager's act irresponsibly and will deviate their interest from owners, therefore board with their legal duties can fix the premises regarding monitoring behavior of managers (Salehi et al. 2020).

Code of Corporate governance stated that strong governed corporations have large, independent board with high participation rate in board meetings so that they can able to manage and monitor executive's operations more transparently. Theoretical literature have mixed views regarding the value relevance of independent board structure as, at one end, agency theory argued that non-executive and independent directors work as a more effective monitoring role on managers and executives. While, on the other end, theory of stewardship stated that board should better be composed of inside directors as they acted as a stewards rather than outside independent directors. 
The role of board governance in financial institutions, especially banks, has been under debate by academicians and practitioners after financial crises. Basel Committee in 2010 also defined new set of rules and regulations for board structure and composition for application of strong corporate governance in banking sector. In light of this, empirical evidences on the impact of board governance on performance have shifted from non-financial to financial firms, especially banking sector. Numerous studies have examined the effect of board composition and independence on bank's profitability (Adams \& Mehran, 2012; Liang et al. 2013; Sarkar \& Subrata, 2018), though the findings vary in nature due to the variations of the corporate governance compliance in each country. In addition, empirical evidence on board governance is mostly concentrated in developed countries and much less has explored regarding the relationship between board governance and bank's performance in developing countries. Present research adds to the standing body of knowledge by examining how board governance influences performance of Pakistani banks. In addition to this, study tests how performance outcomes of such board governance vary with the bank size as large sized firms expect to perform better as compared to small sized firms.

The organization of remaining paper is as follows: second section highlights the empirical literature with research gap and hypothesis development. Third section describes data and methodology, while fourth section reports empirical results with discussions. The last part concludes the study with policy implications and future directions.

\section{Literature Review}

The present paper accepts the corporate governance explanation provided by Zingales (1998), who identifies corporate governance as different mechanisms employed by shareholder has to observe and control management through directors. Literature has widely accepted that no single theory determines the motives behind the broad arrays of association between the board governance and bank's performance. While analyzing existing studies and developing relevant research hypothesis, literature has identified number of theories behind corporate governance role in deriving firm performance. Firstly, agency theory highlights the role of board structure in determining the organization's performance. Theory argued that strong board minimizes the opportunities behaviors of managers by strict governance, which ultimately has positive impact on performance (Jensen \& Meckling, 1976).

Notably, strong board governance represents one with the larger board size and greater proportion of outside or independent directors, though the last one might plays a more significant role in monitoring and controlling managerial activities. Yet, agency theory identifies an upper limit on size of board of directors as larger board might limits the coordination and decision-making power of directors (Yermack, 1996). Hence, a possible trade-off exists between the board size and bank's performance. Contrary to this, stewardship theory argues there exists no agency cost as managers are agents of an organization and hence works in the good interest of shareholders. Inside directors identify as good decision makers and who are capable of increasing the organization's profit due to better understanding of firm's internal operations (Donaldson, 1990). Therefore, according to this theory, board should have higher number of inside directors rather than outside ones for good decisions.

Resource Dependency Theory (Pfeffer, 1972) has also described another description about the functions of board structure. It explains that large and diverse board provides extra networking and greater access to external resources, which are not possible otherwise (Kiel \& Nicholson, 2003). Besides this, Managerial Hegemony Theory by Mace (1979) and Vance (1983) argued that directors give advice, provide disciplinary rules, regulation and make valuable decisions in times of crises but they are less likely to have control over management or to question about sensitive issues. In short, managers, under managerial hegemony approach, want directors to have a passive role in controlling and monitoring firm's operations. These theories support an earlier work of Hillman and Dalziel (2003) that highlights two main functions of board of directors: at first, to control and monitor management on behalf of stockholders, consistent with the agency theory. At second, to ensure an availability of required resources by an organization, supporting Resource Dependence Theory.

A great number of empirical studies has tested the link between corporate governance and performance of nonfinancial firms (e.g., Gupta et al. 2013) in comparison to banking sector. Existing literature identifies that the board organization might perform a more significant part in the regulated sector (banks) other than non-regulated sectors (non-financial firms). The reason behind this is that the banking business is more complicated and impervious which increases the presence of informational asymmetry and therefore demands more monitoring (Levine, 2004). In addition to this, financial regulations have a significant role in banking sector as at one end regulations serve as an additional monitoring tool (Andres \& Vallelado, 2008), while at the other end, they might create governance issue due to the conflict between the shareholders and regulators as they both want to maximize their personal interests (Laeven \& Levine, 2009). Hence, considering the scope of this study, present study gives a summarized review of the current 
literature, specifically done on the banking sector. However, the analysis of literature is restricted to the development of hypothesis only.

\subsection{Board Composition}

Corporate governance, all over the world, demands listed companies to have both inside and outside directors on their board structure. The query of whether board having outside directors' effects firm performance positively is still one of the utmost unclear part of corporate governance. Agency theory argued that there exist a conflict among managers and stockholders (Fama \& Jensen, 1983) and board, in presence of such conflicts, behaves better only if it consists of higher proportion of independent directors on the board. Corporate governance in this scenario, proposes that it is essential to have necessary monitoring mechanisms to safeguard shareholders from manager's personal interests. Hence, a greater proportion of outside directors on board is considering as a driving force behind company's performance (Jensen \& Meckling, 1976; Fama \& Jensen, 1983; Majeed et al., 2020).

Contrary to it, academic literature also brings a doubt regarding the independent directors' skills, capabilities and knowledge. They raised an issue that whether independent directors possess such skills and knowledge which enhance performance. Management, in this case, is more involved in sub-optimal investment decisions that negatively effects performance (Raheja, 2005; Harris \& Raviv, 2008). Limited researchers have found concave relationship between presence of outside directors and firm performance (Adams \& Mehran, 2012), while some studies observe no relationship between independent directors and performance (Hermalin \& Weisbach, 1998; James \& Joseph, 2015). Study however, on grounds of agency theory, hypothesizes that:

$\boldsymbol{H}_{1 a}:$ Higher proportion of outside directors on board influences bank's performance positively.

\subsection{Board Size}

Resource Dependence theory argued that board directors might possess high external links, which help firms to improve their access to external resources that ultimately improves governance and performance. Academic studies, based on management discipline, also consider board of directors as a main driver behind company's performance (Nicholson \& Kiel, 2007). Few researchers found that board performance link with the board's capability to bring significant resources is higher in large size board as compare to small size ones (Korac-Kakabadse et al., 2001).

Board size becomes a debatable issue specifically after business failures of large companies. Academic literature argued that large number of directors bring more knowledge and expertise than a smaller board (Van Den Berghe \& Levrau, 2004). In addition to this, empirical studies also found that large board helps them to minimize the dominating role of CEO (Forbes \& Milliken, 1999). Meanwhile, empirical studies depicted negative impact of board size on performance. Yermack (1996) identified small board as more effective in contrast to a large one as week internal connections and decision making power outweight the cost of larger board by profits. Jensen (1993) argued that large boards (having seven or more members) are less likely to perform effectively, as problems in internal communication, controlling, monitoring and flexible decision-making skills have shifted controlling power to CEOs. While, boards having small number of directors are able to perform more effectively due to higher coordination between them (Eisenberg et al., 1998). Other stream of literature has suggested that an optimal number of directors on board leads to high performance (Andres \& Vellelado, 2008). Hence, concluding the above discussion, the study hypothesizes that:

$\boldsymbol{H}_{2 a}:$ Number of directors on board influences bank's performance positive/ negatively.

\subsection{Board Activity}

Board activity, identified as board meetings, has identified as another element that links the Resource Dependence Theory with corporate governance. One stream of literature found that firms having higher board meetings are more likely to perform better (Lipton \& Lorsch, 1992), while another line of literature argued that routine or daily based activities take a greater portion of board's meeting's time and hence minimize the chances of outside directors to monitor and control management in shareholder's best interest (Jensen, 1993). In this scenario, boards are generally inactive and hence gives a signal of poor performance.

Empirical findings, however, shows complex relationship between board meetings and performance, hence need to explore more. For instance, Vafeas (1999) depicted that market positively perceived boards having higher number of meetings. As board, in return to current year poor performance, increases frequency of meetings that results in higher operating performance in future period, hence indicating a positive effect of current year board meetings on firm's future performance. The literature, though, argued that there are factors other than the number of meetings that need to evaluate carefully while testing the relationship between board activity and performance. For example; quality of meetings, exchange of ideas, proportion of time given to important issues, etc. Concluding the above debate, the 
study identifies board meetings as an important element for influencing board governance and performance. Therefore, in light of current literature, following supposition has made:

$\boldsymbol{H}_{3 a^{*}}:$ Board activity influences bank's performance
sitively.

\section{Empirical Methodology}

Sample data consisted of unbalanced panel data of 19 banks listed on Pakistan Stock Exchange for the period from 2010 to 2017. Data represented almost more than 50\% market share of PSX 100 index and included three public and 16 private banks. The total assets of banks represented almost $80 \%$ of the market share of the Pakistani banking sector in year 2016. Pakistani banks followed International Accounting Standards (IAS), so the financial information had gathered from their respective annual reports. The data on board structure had collected from the notes and director's information section of the annual reports. In case, if banks did not report information regarding independent directors separately, the required information gathered by director's biographies. Study assumed that, if directors had no other position in that particular bank nor had any such relationship with the bank management and block holders that can affect his independent judgment, he/she would classified as an independent director. Likewise, if directors had no executive positive in a company but may have some ownership in a company, he/she would categorized as nonexecutive director.

The primary model of this research is described below:

$$
\begin{aligned}
\text { Bank performance }=\alpha & +\sum_{\mathrm{j}} \beta \mathrm{j} \text { Board Specific vairaibles } \mathrm{s}_{\mathrm{i}, \mathrm{t}}^{\mathrm{j}} \\
& +\delta_{\mathrm{j}} \text { Bank Specific Variables } \mathrm{i}_{\mathrm{i}, \mathrm{t}}^{\mathrm{j}}+\varepsilon_{\mathrm{i}, \mathrm{t}}
\end{aligned}
$$

Where $\mathrm{i}$ depicts banks from 1 to 20 and $\mathrm{t}$ represents the values from 2010-2016. The $\beta$ and $\delta$ captures the effects of board specific and bank specific variables.

Following existing literature (Stancic et al., 2012; Staikouras et al., 2007; Jackling \& Johl, 2009), study employed four different measures of bank performance for empirical analysis. Firstly, Return-on-Asset (ROA), an extensively-used measure of performance in current studies
(Pisedtasalasai \& Edirisuriya, 2020; Duong et al., 2020), was measured by taking the ratio of net income to total assets. It indicates how efficiently bank can generate income by using its assets. Secondly, Net Interest Margin (NIM), calculated by deducting interest expense from interest income. For data normalization, the value had scaled by total assets. This shows the ability of a firm to earn interest income after adjusting all interest expenses. Thirdly, Tobin's Q (Q), represented market performance, was determined by adding market value of equity and liabilities. The value had then be divided by total assets. It shows investor's valuation of banks, as ratio will be higher if investors positively value firms and vice versa. Fourthly, study used Economic Value Addition (EVA) for measuring bank's economic performance, computed by subtracting the cost of capital from bank's invested capital. All four measures have a positive correlation with the bank's performance.

Backed by existing literature, four different indicators were used for board governance: board size, activity, participation, and composition. Number of directors working on the board represented Board Size (BS). Board Activity (ACT) depicted the total board meetings throughout a year, while, Board Participation (PR) showed how many board members attend a meeting during a year. Study used two different proxies for board composition: first, Board Independence (IND) calculated by the proportion of independent directors to total directors on the board; second, the presence of non-executive members on the board (NEX) measured in terms of ratio. Grounded on existing literature, the study used few control variables that might influence bank's performance. Leverage (LEV) was measured by dividing bank debt by total assets. Bank liquidity (LIQ) computed by taking fraction of current assets to current liabilities. Size (SIZE) calculated by natural $\log$ of total assets, while, Age (AGE) showed the total number of years from the time of incorporation.

Table 1 describes how board characteristics varied with the type of the bank. Statistics depicted that public banks had higher board size as compared to the private banks and size ranges from 4-12 in private banks and 6-3 in public banks. Despite of small board size, private banks demonstrated higher activity level and participation rate in contrast to public banks. Presence of non-executive directors in private banks varied from $29 \%-28 \%$, while public banks had nonexecutive directors from $13 \%-92 \%$.

Table 1: Summary Statistics by Type of Ownership

\begin{tabular}{|l|c|c|c|c|c|c|c|c|}
\hline & \multicolumn{2}{|c|}{ Board Size } & \multicolumn{2}{c|}{ Activity } & \multicolumn{2}{c|}{ Participation } & \multicolumn{2}{c|}{ Non-Executive Directors } \\
\hline & Min & Max & Min & Max & Min & Max & Min & Max \\
\hline Private & 4 & 12 & 5 & 17 & 0.54 & 0.96 & 0.29 & 0.78 \\
\hline Public & 6 & 13 & 4 & 12 & 0.35 & 1 & 0.13 & 0.92 \\
\hline
\end{tabular}




\section{Results}

The present paper tested the effect of different board structure aspects and bank specific factors on bank performance. Table 3 reported descriptive statistics of dependent, independent and control variables. Panel A showed descriptive of performance based variables and depict that Pakistani banks have high market and accounting performance, despite of only 5\% economic value contribution. In addition, banks had lower NIM, 4\%, representing that banks perhaps earn more from non-interest income sources rather than interest income sources. Panel B showed descriptive statistics of board structure variables. Statistics illustrated that Pakistani banks had on average 8 board members which is smaller as compared to the developed countries (Liang et al., 2013; Adam \& Mehran, 2005; Georgantopoulos \& Filos, 2017). On average, frequency of board meetings was six in a year, which is again smaller than developed countries, however, almost $79 \%$ participation had been found in board meetings, which indicates the active role of board members in meetings. $29 \%$ board members were found to be independent, $58 \%$ were non-executive while $15 \%$ were executive board members.

Banks had, on average, high leverage ratio due to their nature of business. However, they had on average lower liquidity ratio. Furthermore, Pakistani banks were mostly private and large size having higher age represented their level of maturity.

Table 3 reported correlation results and findings showed that there existed no multicollinearity issue between independent variables. Board size showed positive correlation with the market variable while board activity tended to correlated negatively with the market performance. Inverse correlation between board size and independent directors indicated that Pakistani banks having greater board size had fewer independent directors. Regression results in Table 4 depicted negative effect of board size on the bank's accounting performance, aligned with the various empirical studies (Liang et al., 2013; Staikouras et al., 2007; Hermalin \& Weisbach, 1998). This negative relationship of board size on performance favored the hypothesis $\mathrm{H}_{2 \mathrm{a}}$ that large board may had negative effect on bank performance due to inefficient governance. This implies that coordination, decisionmaking power and level of communication in large board may overcome the advantages of beneficial group information, which results in weak advisory and monitoring functions of the Pakistani bank. However, this relationship turned to be positive, while regressing the board size against market performance. This supports that investors positively value firms having large board structure as they may believe that large board my bring a great intellectual knowledge than smaller board; which in turn improves decision making parts of directors and improves bank's performance. Outcomes align with Jackling and Johl (2009) and Nicholson and Kiel (2007).
Board activity (number of meetings and business) depicted significant negative effect on bank performance, opposing Resource Dependence Theory. Jensen (1993) argued that higher time taken by board meeting, for routine activities, minimized the chances for outside directors to apply some significant control on management. Hence, higher board activity resulted in poor bank performance except NIM. This indicates that Pakistani boards were more tend to discuss their routine activities in meetings and ignored other positive NPV projects. Hence, despite of higher NIM, Pakistani banks had lower accounting, market and economic performance. Empirical analysis regarding the link between board participation and bank performance indicators depicted similar results. Findings, hence, implies that higher board participation lead to poor bank performance as directors are more involved in discussion over routine tasks rather than discussion on new and complex changing environments, which results in adverse effect on bank performance. Board independence depicted insignificant effect on bank performance, opposing Georgantopoulos and Filos, 2017; Jackling and Johl, 2009; Liang et al., 2013. This implies that independent directors sometimes belong to other educational or professional background and hence may not have sufficient information about bank related factors, which nullify the benefits acquired from the enhanced monitoring quality. (Liang et al., 2013).

Table 2: Descriptive Statistics

\begin{tabular}{|l|c|c|}
\hline Variables & Mean & S.D \\
\hline Panel A: Bank performance Variables \\
\hline Q & 83.38 & 62.54 \\
\hline ROA & 1.59 & 5.85 \\
\hline EVA & 0.07 & 0.08 \\
\hline NIM & 0.04 & 0.08 \\
\hline Panel B: Board Characteristics variables \\
\hline BS & 8.81 & 1.87 \\
\hline ACT & 6.66 & 2.35 \\
\hline PR & 0.80 & 0.15 \\
\hline IND & 0.29 & 0.17 \\
\hline NEX & 0.58 & 0.18 \\
\hline EXE & 0.15 & 0.07 \\
\hline Panel C: Other Control Variables \\
\hline LEV & 16.60 & 50.19 \\
\hline LIQ & 1.02 & 0.17 \\
\hline AGE & 33.24 & 33.87 \\
\hline SIZE & 19.55 & 1.05 \\
\hline OWN & 0.98 & 0.15 \\
\hline
\end{tabular}


Findings, furthermore, reported significant negative effect of non-executive directors on bank performance. This probably because of the prevalence of cozy relationship between non-executive directors and executive directors, that limits the monitoring role of non-executive directors on board performance. Kang et al. (2007) also mentioned that, in reality, independent directors represented an "old boys" network and due to their personalized selections and appointment by executive directors, they may feel gratitude towards those who appoint them. Regarding control variables, leverage provided mixed evidence as high leverage negatively affected banks market performance but positively influenced accounting profits. Liquidity, age and firm size influenced bank performance positively.

Table 3: Correlation Matrix

\begin{tabular}{|c|c|c|c|c|c|c|c|c|c|c|c|c|c|c|c|}
\hline Variables & $\mathbf{Q}$ & ROA & NIM & EVA & BS & ACT & PR & IND & NEX & EXE & NPL & LEV & LIQ & AGE & SIZE \\
\hline$Q$ & 1 & & & & & & & & & & & & & & \\
\hline ROA & 0.1 & 1 & & & & & & & & & & & & & \\
\hline NIM & 0.0 & 0.0 & 1 & & & & & & & & & & & & \\
\hline EVA & 0.0 & 0.0 & 0.0 & 1 & & & & & & & & & & & \\
\hline BS & $0.2^{*}$ & 0.0 & 0.0 & -0.1 & 1 & & & & & & & & & & \\
\hline ACT & $-0.2^{*}$ & 0.0 & 0.0 & 0.0 & -0.1 & 1 & & & & & & & & & \\
\hline PR & 0.1 & 0.0 & 0.0 & 0.0 & -0.1 & $-0.2^{*}$ & 1 & & & & & & & & \\
\hline IND & -0.1 & 0.0 & -0.1 & 0.0 & $-0.3^{*}$ & 0.1 & 0.0 & 1 & & & & & & & \\
\hline NEX & 0.1 & 0.0 & 0.0 & 0.0 & -0.1 & -0.0 & 0.0 & $-0.3^{*}$ & 1 & & & & & & \\
\hline EXE & $-0.1^{*}$ & 0.0 & -0.0 & 0.0 & $-0.4^{*}$ & 0.0 & 0.1 & $0.3^{*}$ & -0.0 & 1 & & & & & \\
\hline NPL & 0.0 & -0.0 & -0.0 & -0.0 & -0.1 & 0.0 & 0.0 & 0.0 & -0.0 & -0.0 & 1 & & & & \\
\hline LEV & -0.0 & -0.0 & -0.0 & -0.0 & 0.0 & 0.1 & -0.0 & -0.0 & -0.0 & -0.0 & -0.0 & 1 & & & \\
\hline LIQ & $0.1^{*}$ & 0.0 & 0.0 & 0.0 & 0.1 & -0.1 & 0.0 & 0.0 & 0.0 & 0.0 & -0.0 & -0.0 & 1 & & \\
\hline AGE & $0.2^{*}$ & 0.1 & 0.0 & 0.0 & -0.1 & -0.0 & 0.0 & 0.1 & $0.1^{*}$ & -0.0 & 0.0 & -0.0 & 0.0 & 1 & \\
\hline SIZE & $0.3^{*}$ & 0.1 & -0.0 & 0.0 & 0.0 & $0.2^{*}$ & $0.1^{*}$ & -0.0 & 0.1 & -0.0 & 0.1 & 0.0 & 0.0 & $0.2^{*}$ & 1 \\
\hline
\end{tabular}

Note: ${ }^{* * *},{ }^{* *}$ and ${ }^{*}$ indicates significance at $1 \%, 5 \%$ and $10 \%$ level of significance based on t-statistics.

Table 4: Generalized Linear Model

\begin{tabular}{|l|c|c|c|c|}
\hline Variable & Q & ROA & NIM & EVA \\
\hline CONT & $-7.29^{* * *}$ & $-30.75^{* * *}$ & $357.96^{* * *}$ & $-4.93^{* * *}$ \\
\hline BS & $-114^{* * *}$ & -0.09 & $-5.20^{* *}$ & $-0.22^{* * *}$ \\
\hline ACT & $-0.88^{* * *}$ & $-0.77^{*}$ & $128.61^{* * *}$ & $-1.20^{* *}$ \\
\hline PR & -0.25 & $-2.87^{*}$ & ---- & -0.70 \\
\hline IND & -0.12 & 3.14 & $-41.76^{* *}$ & 0.53 \\
\hline NEX & $-0.09^{* * *}$ & --- & $0.05^{* *}$ & 0.007 \\
\hline LEV & $-0.02^{* * *}$ & $0.01^{*}$ & $-5.82^{* *}$ & 0.20 \\
\hline LIQ & $4.05^{* * *}$ & $15.91^{* * *}$ & $0.41^{* * *}$ & $-0.01^{*}$ \\
\hline AGE & $0.004^{* * *}$ & 0.01 & $-26.60^{* * *}$ & $0.285^{* * *}$ \\
\hline SIZE & $0.37^{* * *}$ & $1.015^{* *}$ & 269.50 & 164.58 \\
\hline LL & -724.47 & -434.20 & -3.75 & -2.24 \\
\hline AIC & 10.55 & 6.37 & -641.31 & -640.72 \\
\hline BIC & 273321.3 & 3564.06 & & \\
\hline
\end{tabular}

Note: ${ }^{* * *},{ }^{* *}$ and * indicates significance at $1 \%, 5 \%$ and $10 \%$ level of significance based on t-statistics. 
Table 5: Test for Moderation

\begin{tabular}{|c|c|c|c|c|c|c|}
\hline & $X=B S$ & $\mathrm{X}=\mathrm{BS}^{2}$ & $\mathrm{X}=\mathrm{BS}^{3}$ & $X=P R$ & $\mathrm{X}=\mathrm{ACT}$ & $X=I N D$ \\
\hline CONT & $11.59^{*}$ & 2.59 & -0.75 & $-32.40^{* * *}$ & $-11.10^{* *}$ & $-5.36^{* *}$ \\
\hline $\mathrm{X}$ & $-2.40^{* * *}$ & $-0.15^{\star \star *}$ & $-0.01^{* * *}$ & $29.58^{* * *}$ & 0.16 & 11.94 \\
\hline SIZE & $-6.55^{\star}$ & -0.20 & -0.025 & $1.55^{* * *}$ & $0.54^{* *}$ & 0.20 \\
\hline INT & $0.12^{* * *}$ & $0.01^{* * *}$ & $0.001^{* * *}$ & $-1.41^{\star \star *}$ & -0.01 & 0.56 \\
\hline ADJ $R^{2}$ & 0.41 & 0.43 & 0.43 & 0.44 & 0.41 & 0.41 \\
\hline F Stat & $15.31^{* * *}$ & $17.16^{* * *}$ & $17.17^{* * *}$ & $17.73^{* * *}$ & $15.08^{* * *}$ & $15.03^{* * *}$ \\
\hline \multicolumn{7}{|c|}{ Conditional Effects } \\
\hline Low & $-0.16^{\star *}$ & $-0.01^{\star *}$ & $-0.01^{* *}$ & $3.439^{* * *}$ & ----- & ------ \\
\hline Moderate & -0.003 & 0.0003 & 0.000 & $1.65^{* * *}$ & ----- & ----- \\
\hline High & $0.12^{* *}$ & $0.01^{* * *}$ & $0.001^{* * *}$ & 0.283 & ----- & ------ \\
\hline
\end{tabular}

Note: ${ }^{* * *},{ }^{* *}$ and * indicates significance at $1 \%, 5 \%$ and $10 \%$ level of significance based on t-statistics.

Existing literature on corporate governance had highlighted how relationship between board structure and bank performance varied with the size of the firm (Isik \& Ince, 2016). Present study, therefore, tested the moderating role of size on the impact of board structure on bank performance. Results in table 5 illustrated that inverse relationship between board size and performance turned to be positive when controlling the effect of bank size. This implies that large size banks have higher incremental effects from large board size as compared to the small one. However, the size of the board was irrelevant to performance in moderate sized banks. Linearity tests indicated that there might be an optimal board size for Pakistani banks as too large board size hindered performance regardless of the bank size.

\section{Conclusion}

The global financial crises of 2007-2008 brings in light the changing performance of the banking sector. Financial regulators, in response, bring significant steps to improve standards of corporate governance in the banking sector as financial weakness lead many banks to liquidating state. Existing studies have generally discussed how Corporate Governance helps banks to minimize risk. However, empirical literature on the role of board structure in driving bank performance is missing in Pakistan, where shareholder's rights have not fully protected. Present study analyzed the effect of board structure, the most pertinent factor of corporate governance, on bank performance by using sample data of 19 Commercial banks of Pakistan over the duration of 2010-2017. Board structure includes size of the board, proportion of non-executive and independent directors on the board, board activity and participation level whereas performance is calculated by accounting, market and economic based measures. Regression analysis also includes bank specific variables.

Results regarding board size is mixed in nature, as banks having large size board is perceived positively by investors, supporting Resource Dependence theory. Meanwhile, large size board reduces bank's accounting and market profits, aligned with Yermark (1996) and Jensen (1993). Similarly, board activity and participation depicts negative effect on performance, again supporting Jensen (1993). However, higher board activity and participation level increase bank's net interest margin. This indicates that boards are allocating their more time on daily activities rather than discussing other strategic decisions. Supporting Raheja (2005), results imply that outside directors (non-executive directors) have fewer information than insider's has. In addition, they do not have necessary skills, knowledge and expertise to make strategic decisions of a regulated sector and hence their presence put downward pressure on bank's profitability. Moreover, this might be due to the limited number of outside directors with relevant expertise in Pakistan. Study opens new endeavors for future researchers as empirical evidence on the effect of board structure on bank's current and future stability is still missing.

\section{References}

Adams, R. B., \& Mehran, H. (2012). Bank Board Structure and Performance: Evidence for Large Bank Holding Companies. Journal of Financial Intermediation, 21(2), 243-267.

Adams, R. B., \& Mehran, H. (2005). Corporate performance, board structure and its determinants in the banking industry. In: EFA 2005 Moscow meetings.

Andres, P. D., \& Vallelado, G. E. (2008). Corporate Governance in Banking: The role of Board of Directors. Journal of Banking and Finance, 32, 2570-2580. 
Donaldson, L. (1990). The ethereal hand: Organizational economics and management theory. Academy of Management Review, 15(3), 369-381.

Duong, T. T. N., Phan, H. T., Hoang, T. N., \& Vo, T. T. T. (2020). Journal of Asian Finance, Economics and Business, 7(9), 75-84. https://doi.org/10.13106/jafeb.2020.vol7.no9.075

Eisenberg, T. S. S., \& Wells, M. T. (1998). Larger board size and decreasing firm value in small firms. Journal of Financial Economics, 48(1), 35-54.

Fama, E. F., \& Jensen, M. C. (1983). Agency problems and residual claims. The Journal of Law and Economics, 26(2), 327-349.

Forbes, D. P., \& Milliken, F. J. (1999). Cognition and corporate governance: Understanding boards of directors as strategic decision-making groups. Academy of Management Review, 24(3), 489-505.

Georgantopoulos, A. G., \& Filos, L. (2017). Board structure and bank performance: Evidence for the Greek banking industry during crisis period. International Journal of Economics and Financial Issues, 7(1), 56-67.

Gupta, K., Krishnamurti, C., \& Tourani-Rad, A. (2013). Is corporate governance relevant during the financial crisis? Journal of International Financial Markets, Institutions and Money, 23, 85-110.

Harris, M., \& Raviv, A. (2008). A theory of board control and size. The Review of Financial Studies, 21(4), 1797-1832.

Hermalin, B. E., \& Weisbach, M. S. (1998). Endogenously chosen boards of directors and their monitoring of the CEO. American Economic Review, 96-118.

Hillman, A. J., \& Dalziel, T. (2003). Boards of directors and firm performance: Integrating agency and resource dependence perspectives. Academy of Management review, 28(3), 383-396.

Isik, O., \& Ince, A. (2016). Board Size, Board Composition and Performance: An Investigation on Turkish Banks. International Business Research, 9(74), 74-84.

Jackling, B., \& Johl, S. (2009). Board structure and firm performance: Evidence from India's top companies. Corporate Governance: An International Review, 17(4), 492-509.

James, B. J., \& Joseph, C. (2015). Corporate governance mechanisms and bank performance: Resource-based view. Procedia Economics and Finance, 31, 117-123.

Jantadej, K., \& Wattanatorn, W. (2020). The effect of corporate governance on the cost of debt: Evidence from Thailand. Journal of Asian Finance, Economics and Business, 7(9), 283291. https://doi.org/10.13106/jafeb.2020.vol7.no9.283

Jensen, M. C. (1993). The modern industrial revolution, exit, and the failure of internal control systems. The Journal of Finance, $48(3), 831-880$.

Jensen, M. C., \& Meckling, W. H. (1976). Theory of the firm: Managerial behavior, agency costs and Ownership Structure. Journal of Financial Economics, 3, 305-360.

Kang, H., Cheng, M., \& Gray, S. J. (2007). Corporate governance and board composition: Diversity and independence of
Australian boards. Corporate Governance: An International Review, 15(2), 194-207.

Kiel, G. C., \& Nicholson, G. J. (2003). Board composition and corporate performance: How the Australian experience informs contrasting theories of corporate governance. Corporate Governance: An International Review, 11(3), 189-205.

Korac-Kakabadse, N., Kakabadse, A. K., \& Kouzmin, A. (2001). Board governance and company performance: any correlations? Corporate Governance: The International Journal of Business in Society, 1(1), 24-30.

Laeven, L., \& Levine, R. (2009). Bank governance, regulation and risk taking. Journal of Financial Economics, 93(2), 259-275.

Levine, R. (2004). The corporate governance of banks: A concise discussion of concepts and evidence. Washington, DC: The World Bank.

Liang, Q., Xu, P. \& Jiraporn, P. (2013). Board characteristics and Chinese bank performance. Journal of Banking \& Finance, 37(8), 2953-2968.

Lipton, M., \& Lorsch, J. W. (1992). A modest proposal for improved corporate governance. The Business Lawyer, 48(1), 59-77.

Mace, M. L. (1979). Directors: Myth and Reality-ten years later. Rutgers Law Review, 32, 293.

Majeed, M. K., Jun, J. C., Zia-ur-Rehman, M., Mohsin, M., \& Rafiq, M. Z. (2020). The Board Siza and Board Composition Impact on Financial Performance: An Evidence from the Pakistani and Chinese's Listed Banking Sector. Journal of Asian Finance, Economics and Business, 7(4), 81-95. https://doi.org/10.13106/ jafeb.2020.vol7.no4.81

Nicholson, G. J., \& Kiel, G. C. (2007). Can directors impact performance? A case-based test of three theories of corporate governance. Corporate Governance: An International Review, 15(4), 585-608.

Pisedtasalasai, A., \& Edirisuriya, P. (2020). Diversification and Performance of Sri lankan Banks. Journal of Asian Finance, Economics and Business, 7(9), 1-10. ttps://doi.org/10.13106/ jafeb.2020.vol7.no9.001

Pfeffer, J. (1972). Size and composition of corporate boards of directors: The organization and its environment. Administrative Science Quarterly, 17(2), 218-228. DOI: 10.2307/2393956

Raheja, C. G. (2005). Determinants of board size and composition: A theory of corporate boards. Journal of Financial and Quantitative Analysis, 40(2). 283-306.

Salehi, M., Arianpoor, A., \& Dalwai, T. (2020). Corporate Governance and Cost of Equity: Evidence from Tehran Stock Exchange. Journal of Asian Finance, Economics and Business, 7(7), 149-158. https://doi.org/10.13106/jafeb.2020.vol7.no7.149

Sarkar, J., \& Subrata, S. (2018). Bank Ownership, Board Characteristics and Performance: Evidence from Commercial Banks in India. International Journal of Financial Studies, 6(1), 17.

Staikouras, P. K., Staikouras, C. K., \& Agoraki, M. K. (2007). The effect of board size and composition on European bank 
performance. European Journal of Law and Economics, 23(1), $1-27$.

Stancic, P., Millan, C., \& Barjaktarovic Rakocevic, S. M. (2012). Influence of Board Size and Composition on Bank Performance: Case of Serbia. Actual Problems of Economics, 134(8), 466-475.

Vafeas, N. (1999). Board meeting frequency and firm performance. Journal of Financial Economics, 53(1), 113-142.

Van den Berghe, L. A. A., \& Levrau, A. (2004). Evaluating boards of directors: what constitutes a good corporate board?. Corporate Governance: An International Review, 12(4), 461-478.
Vance, S. C. (1983). Corporate Leadership, Boards, Directors and Strategy. New York, NY: McGraw-Hill.

Yermack, D. (1996). Higher market valuation of companies with a small board of directors. Journal of Financial Economics, $40(2), 185-211$.

Zingales, L. (1998). Corporate Governance. The New Palgrave Dictionary of Economics and Law, London, UK: Palgrave Macmillan. 